\title{
Hubungan Usia Gestasi dan Kadar Hemoglobin Trimester 3 Kehamilan dengan Berat Lahir Bayi
}

\section{Correlation Between Gestational Age and Hemoglobin Level on 3rd Trimester of Pregnancy with Birth Weight of Infants}

\author{
Denna Rahinda Yulia Fanni*1, Merryana Adriani ${ }^{1}$
}

\begin{abstract}
ABSTRAK
Latabelakang: Kejadian BBLR merupakan salah satu permasalahan kesehatan di Indonesia yang masih harus ditangani dengan baik. Hal ini dapat terjadi karena beberapa faktor salah satunya adalah usia gestasi dan kadar $\mathrm{Hb}$ trimester 3 kehamilan yang dimiliki ibu saat kehamilan. BBLR dapat menimbulkan beberapa masalah kesehatan pada bayi seperti penyakit infeksi, gangguan pernafasan, dan gangguan sistem saraf pusat.

Tujuan: Penelitian ini memiliki tujuan untuk menganalisis hubungan usia gestasi dan kadar $\mathrm{Hb}$ trimester 3 kehamilan dengan berat lahir bayi di wilayah kerja Puskesmas Tambak Wedi Surabaya. Metode: Penelitian ini menggunakan desain cross sectional dengan besar sampel sebanyak 60 responden dimana dipilih dengan sistem simple random sampling. Instrumen yang digunakan adalah lembar kuisioner karakteristik ibu dan bayi serta lembar FFQ untuk wawancara pola konsumsi kehamilan. Analisis data menggunakan uji statistik chi square.

Hasil: Terdapat hubungan antara usia gestasi $(p$-value $=0,002)$ dan kadar hemoglobin trimester 3 kehamilan $(p$-value $=0,044)$ dengan berat lahir bayi.

Kesimpulan: Variabel usia gestasi dan kadar $\mathrm{Hb}$ trimester 3 kehamilan memiliki hubungan dengan berat lahir bayi di wilayah kerja Puskesmas Tambak Wedi Surabaya.Usia gestasi yang tergolong tidak berisiko untuk melahirkan bayi BBLR adalah usia gestasi $>38$ minggu sedangkan kadar $\mathrm{Hb}$ trimester 3 kehamilan yang tergolong tidak berisiko untuk melahirkan bayi BBLR adalah $>11 \mathrm{~g} / \mathrm{dl}$.
\end{abstract}

Kata Kunci: BBLR, usia gestasi, hemoglobin, kehamilan 


\begin{abstract}
Background: The incidence of $L B W$ is one of the health issues in Indonesia that still needs to be handled properly. This can be happen because of several factors which are gestational age and the $3 r d$ trimester $\mathrm{Hb}$ level of pregnancy that the mother had during pregnancy. LBW may cause some health issues for infants such as infectious diseases, respiratory disorders, and central nervous system disorders.

Objectives: This research has purpose to analyze relationship between gestational age and 3rd trimester $\mathrm{Hb}$ level of pregnancy with infant birth weight in working area of Tambak Wedi Surabaya Community Health Center.

Method: This study used cross sectional design with 60 respondents as sample of research where chosen by simple random sampling system. The instruments that used were mother and baby characteristic questionnaire sheets and FFQ sheets for interviewing pregnancy consumption patterns. Data analysed using chi square statistic test.

Results: There was a relationship between gestational age $(p$-value $=0.002)$ and $3 r d$ trimester hemoglobin levels of pregnancy ( $p$-value $=0.044)$ with infant birth weight.

Conclusion: The variable of gestational age and the 3rd trimester $\mathrm{Hb}$ level of pregnancy has a relationship with the birth weight of infants in the working area of Tambak Wedi Surabaya Community Health Center. Gestational age which isn't considered risky to give birth to LBW infants are gestational age $>38$ weeks while the 3rd trimester Hb level of pregnancy that isn't classified risky to give birth to $L B W$ baby is $>11 \mathrm{~g} / \mathrm{dl}$.
\end{abstract}

Keywords: LBW, gestational age, hemoglobin, pregnancy

\footnotetext{
*Koresponden:

dennafanni@gmail.com

${ }^{1}$ Departemen Gizi Kesehatan, Fakultas

Kesehatan Masyarakat-Universitas Airlangga
} 


\section{PENDAHULUAN}

Berat lahir bayi yang rendah atau dikenal dengan singkatan BBLR merupakan salah satu masalah kesehatan yang masih dapat ditemukan di Indonesia. BBLR merupakan kondisi dimana bayi yang baru dilahirkan memiliki berat sebesar $<2.500$ gram $^{1}$. Kejadian BBLR dapat terjadi karena beberapa faktor seperti anemia, status gizi ibu hamil, dan peningkatan berat badan selama kehamilan². Faktor lain yang juga dapat mempengaruhi berat lahir bayi adalah usia yang dimiliki ibu ketika mengandung bayi ${ }^{3}$. Berat lahir bayi dapat dikategorikan menjadi tiga yakni berat lahir bayi rendah dengan berat $<2.500$ gram, berat lahir normal dengan berat 2.500-3.999 gram, dan berat lahir lebih dengan berat $\geq 4.000$ gram $^{4}$.

Prevalensi BBLR yang dapat di temukan di Indonesia tahun 2013 sebesar $10,2 \%$ dimana salah satu provinsi dengan jumlah prevalensi BBLR yang cukup banyak adalah Jawa Timur dengan prevalensi sebesar $11,2 \%^{4}$. Salah satu kota dengan prevalensi BBLR yang cukup banyak di Jawa Timur adalah kota Surabaya dengan besar persentase $2,58 \%$. Salah satu kecamatan dengan jumlah persentase kejadian BBLR yang cukup besar di Surabaya adalah Kecamatan Kenjeran dengan 4 puskesmas yang bekerja di wilayah tersebut. Puskesmas dengan jumlah persentase BBLR terbesar di kecamatan Kenjeran adalah Puskesmas Tambak Wedi dengan besar persentase kejadian BBLR tahun 2016 sebesar $8,75 \%$. Jumlah persentase ini mengalami peningkatan cukup besar dari tahun sebelumnya dimana besar persentase kejadian BBLR yang ditemukan di wilayah kerja Puskesmas Tambak Wedi Surabaya adalah $3,13 \%{ }^{5}$. Hal tersebut menandakan bahwa permasalahan bayi dengan berat lahir rendah belum terselesaikan dan harus segera ditangani dengan baik.

Berat lahir yang rendah pada bayi dapat menyebabkan masalah kesehatan pada bayi di kemudian hari seperti adanya penyakit infeksi, gangguan pada sistem pernafasan, gangguan pada saraf pusat, gangguan pada fungsi kardiovaskuler, gangguan pada sistem gastrointestinal, dan sebagainya ${ }^{6}$.

Salah satu faktor yang berhubungan dengan berat lahir bayi adalah usia gestasi ${ }^{7}$. Usia gestasi atau usia kehamilan merupakan waktu yang dibutuhkan seorang ibu selama masa konsepsi hingga kelahiran ${ }^{8}$. Usia gestasi terbagi menjadi tiga golongan yakni usia gestasi awal (pre term) dengan usia kehamilan $<38$ minggu, usia gestasi penuh (term) dengan usia kehamilan antara 38-42 minggu, dan usia gestasi terlewat (post term) dengan usia kehamilan $>42$ minggu $^{9}$. Klasifikasi berat lahir bayi dapat dilakukan berdasarkan usia gestasi yang dimiliki ibu dimana terbagi menjadi 3 yakni berat lahir kecil menurut usia gestasi (small for gestational age/SGA), berat lahir cukup menurut usia gestasi (appropriate for gestational age/AGA), dan berat lahir besar menurut usia gestasi (large for gestational age/ $(G A)^{10}$.

Faktor lain yang juga berhubungan dengan berat lahir bayi adalah kadar hemoglobin ibu saat kehamilan trimester $3^{11}$. Pemeriksaan kadar hemoglobin $(\mathrm{Hb})$ selama kehamilan merupakan pemeriksaan yang penting dilakukan bagi ibu hamil. Hal ini dilakukan untuk mengetahui kejadian anemia sedini mungkin. Pada pemeriksaan kadar hemoglobin selama kehamilan, hasil yang didapatkan akan menunjukkan tingkat keparahan anemia yang dimiliki ibu ${ }^{12}$. Anemia adalah keadaan dimana sirkulasi sel darah merah mengalami penurunan dari batas normal dimana ibu hamil yang tergolong anemia memiliki kadar $\mathrm{Hb}<11 \mathrm{~g} / \mathrm{dl}^{13}$.

Pada saat kehamilan, volume plasma, volume dan massa sel darah merah mengalami peningkatan. Peningkatan yang terjadi pada volume darah menyebabkan turunnya konsentrasi $\mathrm{Hb}$ dan hematokrit dimana penurunan konsentrasi $\mathrm{Hb}$ dikenal dengan sebutan anemia delusional. Puncak kejadian anemia delusional saat kehamilan adalah pada trimester 2 dan akan kembali normal pada trimester $3^{14}$. Penelitian ini memiliki tujuan untuk menganalisis hubungan antara usia gestasi dan kadar hemoglobin trimester 3 kehamilan dengan berat lahir bayi 
di wilayah kerja Puskesmas Tambak Wedi Surabaya.

\section{METODE}

Penelitian ini merupakan penelitian observasional dengan desain cross sectional. Populasi penelitian sebanyak 350 orang dimana sampel penelitian adalah semua ibu dengan bayi yang lahir pada bulan Januari hingga Mei tahun 2017 dimana tinggal di wilayah kerja Puskesmas Tambak Wedi Surabaya. Besar sampel dalam penelitian ini dihitung menggunakan rumus Slovin ${ }^{15}$ dimana didapatkan hasil besar sampel minimal 54 dengan nilai presisi sebesar $10 \%$ sehingga jumlah sampel yang digunakan dalam penelitian adalah 60 orang. Daftar nama responden didapatkan dari data kohort yang dimiliki Puskesmas Tambak Wedi. Semua sampel penelitian ini dipilih dengan menggunakan metode simple random sampling atau pemilihan sampel secara acak dengan menggunakan kertas undian sebanyak jumlah sampel yang diinginkan. Kriteria inklusi penelitian adalah ibu dengan bayi yang lahir pada bulan Januari hingga Mei tahun 2017, tinggal di wilayah kerja Puskesmas Tambak Wedi Surabaya, memiliki buku KIA, dan bersedia mengikuti penelitian. Kriteria eksklusi penelitian adalah ibu dengan bayi yang mengalami infeksi dan ibu dengan bayi lahir kembar. Penelitian ini dilakukan di wilayah kerja Puskesmas Tambak Wedi Surabaya pada bulan Juli tahun 2017.

Karakteristik ibu dan bayi yang diambil dalam penelitian ini adalah usia ibu, usia gestasi, kadar hemoglobin, pola konsumsi ibu selama kehamilan, jarak kelahiran, paritas, dan berat lahir bayi. Jenis data yang diambil dalam penelitian adalah data primer dan data sekunder. Data primer yang diambil adalah pola konsumsi selama kehamilan yang dimiliki ibu menggunakan lembar FFQ (Food Frequency Questionnaire) sedangkan data sekunder adalah usia ibu, usia gestasi, kadar hemoglobin, jarak kelahiran, paritas, dan berat lahir bayi.

Analisis yang dilakukan dalam penelitian ini terdiri atas analisis univariat dan analisis bivariat. Analisis univariat dalam penelitian ini dilakukan untuk mengetahui distribusi variabel yang termasuk dalam karakteristik ibu dan bayi. Analisis bivariat dalam penelitian ini dilakukan untuk mengetahui hubungan antara variabel usia gestasi dan kadar hemoglobin trimester 3 kehamilan dengan berat lahir bayi menggunakan uji chi square.

Penelitian ini telah dipresentasikan pada Komisi Kaji Etik Fakultas Kesehatan Masyarakat Universitas Airlangga dengan nomor sertifikat 349-KEPK. Inform consent untuk responden penelitian telah didapatkan dari seluruh ibu dan bayi yang menjadi responden pada penelitian ini.

\section{HASIL DAN PEMBAHASAN}

Hasil distribusi karakteristik ibu dan bayi dalam penelitian ini dapat dilihat pada Tabel 1 dimana menunjukkan bahwa mayoritas responden berusia 20-35 tahun dengan jumlah 44 ibu atau sebesar $73,33 \%$ dari keseluruhan responden penelitian. Responden yang tergolong dalam usia berisiko yakni $<20$ tahun dan $>35$ tahun berjumlah sama yakni 8 orang dengan besar persentase yang tidak jauh berbeda. Hal tersebut menandakan bahwa sebagian besar ibu tergolong memiliki usia reproduksi yang aman dan mengurangi risiko terjadinya berat lahir tidak normal. Ibu hamil dengan usia $<20$ tahun memiliki risiko lebih besar melahirkan bayi prematur dan BBLR, mengalami pendarahan saat persalianan, dan terjadinya kematian bagi ibu maupun janin dibanding dengan ibu hamil yang memiliki usia antara 20-35 tahun?. Ibu hamil dengan usia $>35$ tahun juga dianggap usia berisiko dikarenakan ibu hamil dengan usia tersebut memiliki kemungkinan lebih besar melahirkan bayi dengan kelainan genetik ${ }^{16}$.

Berdasarkan Tabel 1 diketahui bahwa mayoritas ibu memiliki usia gestasi yang tergolong penuh yakni berkisar antara 38-42 minggu dengan jumlah 41 responden atau $68,33 \%$. Jumlah terbanyak kedua adalah ibu dengan usia gestasi yang tergolong awal yakni < 38 minggu dengan jumlah 17 responden atau $28,33 \%$. Hal tersebut menandakan bahwa sebagian besar ibu melahirkan bayi pada usia gestasi yang tergolong penuh dan memiliki 
Tabel 1. Distribusi Karakteristik Ibu dan Bayi di Wilayah Kerja Puskesmas Tambak Wedi 2017

\begin{tabular}{|c|c|c|}
\hline Karakteristik Responden & $\mathbf{n}$ & $\%$ \\
\hline \multicolumn{3}{|l|}{ Usia (tahun) } \\
\hline$<20$ & 8 & 13,33 \\
\hline $20-35$ & 44 & 73,33 \\
\hline$>35$ & 8 & 13,34 \\
\hline Total & 60 & 100,00 \\
\hline \multicolumn{3}{|l|}{ Usia Gestasi (minggu) } \\
\hline$<38$ & 17 & 28,33 \\
\hline $38-42$ & 41 & 68,33 \\
\hline$>42$ & 2 & 3,34 \\
\hline Total & 60 & 100,00 \\
\hline \multicolumn{3}{|l|}{ Kadar Hemoglobin Trimester 3 Kehamilan (g/dl) } \\
\hline$<11$ & 19 & 31,67 \\
\hline$>11$ & 41 & 68,33 \\
\hline Total & 60 & 100,00 \\
\hline \multicolumn{3}{|l|}{ Pola Konsumsi (per hari) } \\
\hline Bahan Makanan Pokok Kurang & 16 & 26,67 \\
\hline Bahan Makanan Pokok Baik & 44 & 73,33 \\
\hline Total & 60 & 100,00 \\
\hline Buah Kurang & 49 & 81,67 \\
\hline Buah Baik & 11 & 18,33 \\
\hline Total & 60 & 100,00 \\
\hline Sayuran Kurang & 57 & 95,00 \\
\hline Sayuran Baik & 3 & 5,00 \\
\hline Total & 60 & 100,00 \\
\hline Lauk Nabati Kurang & 17 & 28,67 \\
\hline Lauk Nabati Baik & 43 & 71,33 \\
\hline Total & 60 & 100,00 \\
\hline Lauk Hewani Kurang & 40 & 66,67 \\
\hline Lauk Hewani Baik & 20 & 33,33 \\
\hline Total & 60 & 100,00 \\
\hline Susu Kurang & 21 & 35,00 \\
\hline Susu Baik & 39 & 65,00 \\
\hline Total & 60 & 100,00 \\
\hline Tablet Tambah Darah Kurang & 38 & 63,33 \\
\hline Tablet Tambah Darah Baik & 22 & 36,67 \\
\hline Total & 60 & 100,00 \\
\hline \multicolumn{3}{|l|}{ Jarak Kelahiran (tahun) } \\
\hline$<2$ & 23 & 38,33 \\
\hline$\geq 2$ & 37 & 61,67 \\
\hline Total & 60 & 100,00 \\
\hline \multicolumn{3}{|l|}{ Paritas } \\
\hline 1 & 20 & 33,33 \\
\hline $2-5$ & 39 & 65,00 \\
\hline$\geq 6$ & 1 & 1,67 \\
\hline Total & 60 & 100,00 \\
\hline \multicolumn{3}{|l|}{ Berat Lahir Bayi } \\
\hline BBLR & 6 & 10,00 \\
\hline BBLN & 53 & 88,33 \\
\hline BBLL & 1 & 1,67 \\
\hline Total & 60 & 100,00 \\
\hline
\end{tabular}


Tabel 2. Hubungan Usia Gestasi dengan Berat Lahir Bayi di Wilayah Kerja Puskesmas Tambak Wedi 2017

\begin{tabular}{|c|c|c|c|c|c|c|c|}
\hline \multirow{3}{*}{$\begin{array}{c}\text { Usia } \\
\text { Gestasi (minggu) }\end{array}$} & \multicolumn{6}{|c|}{ Berat Lahir Bayi (gram) } & \multirow{3}{*}{$p$ value } \\
\hline & \multicolumn{2}{|c|}{$\begin{array}{c}\text { BBLR } \\
<2.500 \\
\end{array}$} & \multicolumn{2}{|c|}{$\begin{array}{c}\text { BBLN } \\
2.500-3.999 \\
\end{array}$} & \multicolumn{2}{|c|}{$\begin{array}{c}\text { BBLL } \\
\geq 4.000\end{array}$} & \\
\hline & $\mathbf{n}$ & $\%$ & $\mathbf{n}$ & $\%$ & $\mathbf{n}$ & $\%$ & \\
\hline Awal (<38 ) & 6 & 100,00 & 11 & 20,75 & 0 & 0 & \\
\hline Penuh (38 - 42) & 0 & 0 & 40 & 75,47 & 1 & 100,00 & רח0 \\
\hline Terlewat (> 42) & 0 & 0 & 2 & 3,78 & 0 & 0 & 0,002 \\
\hline Total & & 100,00 & 53 & 100,00 & 1 & 100,00 & \\
\hline
\end{tabular}

Tabel 3. Hubungan Kadar Hemoglobin Trimester 3 dengan Berat Lahir Bayi di Wilayah Kerja Puskesmas Tambak Wedi 2017

\begin{tabular}{|c|c|c|c|c|c|c|c|}
\hline \multirow{3}{*}{$\begin{array}{c}\text { Kadar Hemoglobin } \\
\text { Trimester } 3 \\
\text { Kehamilan (g/dl) }\end{array}$} & \multicolumn{6}{|c|}{ Berat Lahir Bayi (gram) } & \multirow{3}{*}{$p$ value } \\
\hline & \multicolumn{2}{|c|}{$\begin{array}{c}\text { BBLR } \\
<2.500 \\
\end{array}$} & \multicolumn{2}{|c|}{$\begin{array}{c}\text { BBLN } \\
2.500-3.999 \\
\end{array}$} & \multicolumn{2}{|c|}{$\begin{array}{c}\text { BBLL } \\
\geq 4.000\end{array}$} & \\
\hline & $n$ & $\%$ & $n$ & $\%$ & $\mathbf{n}$ & $\%$ & \\
\hline$<11$ & 4 & 66,67 & 14 & 26,41 & 1 & 100,00 & \\
\hline$>11$ & 2 & 33,33 & 39 & 73,59 & 0 & 0,00 & 0,044 \\
\hline Total & 6 & 100,00 & 53 & 100,00 & 1 & 100,00 & \\
\hline
\end{tabular}

risiko lebih kecil melahirkan bayi BBLR. Kelahiran prematur atau kelahiran dengan usia gestasi < 38 minggu merupakan kelahiran bayi yang bisa terjadi karena salah satu faktor yakni gangguan pertumbuhan selama dalam kandungan ${ }^{17}$. Tabel 1 menunjukkan bahwa hasil distribusi kadar hemoglobin trimester 3 kehamilan yang dimiliki responden penelitian sebagian besar tergolong tidak anemia dengan kadar $\mathrm{Hb}>11 \mathrm{mg} / \mathrm{dl}$.

Jumlah responden yang tidak mengalami anemia sebanyak 41 responden atau 68,33\%. Hal ini menandakan bahwa sebagian besar ibu tidak mengalami anemia selama kehamilannya. Ibu hamil yang mengalami anemia saat kehamilannya memiliki risiko melahirkan bayi BBLR 3 kali lebih besar dibanding ibu hamil yang tidak mengalami anemia ${ }^{18}$.

Berdasarkan hasil wawancara pola konsumsi selama kehamilan, diketahui bahwa sebagian besar ibu hanya mengonsumsi beberapa jenis bahan makanan sesuai yang dianjurkan yakni bahan makanan pokok, lauk nabati, dan susu. Sebagian besar responden mengatakan bahwa lauk yang selalu dikonsumsi setiap kali makan adalah tahu dan tempe sedangkan lauk hewani seperti ayam, telur, dan ikan laut hanya dikonsumsi 2-3 kali seminggu. Konsumsi tablet tambah darah yang tergolong kurang dapat terjadi dikarenakan kebanyakan ibu lupa mengkonsumsi dan tidak mengerti kegunaan tablet tambah darah bagi ibu hamil. Konsumsi lauk daging dan tablet tambah darah yang kurang dapat berpengaruh terhadap kadar $\mathrm{Hb}$ saat kehamilan dikarenakan hubungannya dengan kejadian anemia. Sumber zat besi yang paling berasal dari sumber zat besi hewani seperti daging ayam, daging sapi, dan sebagainya ${ }^{19}$.

Hasil distribusi penelitian juga menunjukkan bahwa sebagian besar ibu memiliki jarak $\geq 2$ tahun dengan jumlah 31 orang atau $61,67 \%$. Hal tersebut menandakan bahwa sebagian besar ibu memiliki jarak kelahiran yang tergolong ideal. Jarak kelahiran $<2$ tahun yang dimiliki ibu dapat meningkatkan risiko kejadian BBLR 3,231 kali lebih besar dibanding ibu dengan jarak kelahiran $\geq 2 \operatorname{tahun}^{20}$. Hasil distribusi paritas responden pada penelitian ini menunjukkan bahwa mayoritas ibu memiliki paritas antara 2-5 dengan jumlah 39 responden atau 65\% dari keseluruhan responden. Jumlah paritas berdasarkan kematian maternal dan perinatal yang dianggap aman berkisar antara 2-3. Semakin besar jumlah paritas yang dimiliki 
maka semakin besar risiko ibu mengalami kematian maternal ${ }^{21}$.

Berdasarkan Tabel 1 diketahui bahwa mayoritas berat lahir bayi yang ditemukan selama penelitian ini tergolong berat lahir bayi yang tergolong normal yakni berkisar antara 2.500-3.999 gram. Jumlah bayi yang tergolong memiliki berat lahir bayi normal sebanyak 53 bayi atau $88,33 \%$ dari seleuruh responden penelitian sedangkan jumlah bayi yang lahir dengan berat lahir rendah sebanyak 6 bayi atau $10,00 \%$ dari keseluruhan responden. Bayi yang lahir dengan berat $\geq 4.000$ gram sebanyak 1 bayi atau $1,67 \%$ dari keseluruhan responden.

Berdasarkan Tabel 2 diketahui bahwa sebagian besar bayi lahir dengan berat badan lahir normal dan usia gestasi penuh dimana memiliki jumlah 40 bayi atau $66,67 \%$ dari keseluruhan responden. Jumlah bayi dengan berat badan lahir rendah sebanyak 6 bayi atau $10 \%$ dimana semuanya lahir dengan usia gestasi tergolong awal. Berdasarkan uji statistik didapatkan nilai $\mathrm{p}=0,002$ dengan $\alpha=0,05$ dimana nilai $p<\alpha=0,05$ yang memiliki arti terdapat hubungan antara usia gestasi dengan berat lahir bayi. Hal ini sesuai dengan penelitian yang pernah dilakukan Sulityorini tahun 2013 dimana ibu dengan usia gestasi kurang dari 38 minggu memiliki risiko melahirkan bayi BBLR 2,204 kali lebih besar dibanding ibu dengan usia gestasi lebih dari 38 minggu ${ }^{22}$.

Hubungan antara usia gestasi dengan berat lahir bayi dapat terjadi karena beberapa kemungkinan yakni berat lahir rendah karena usia gestasi yang tergolong awal, berat lahir rendah dengan usia gestasi yang tergolong normal, dan kombinasi dari dua kemungkinan sebelumnya ${ }^{23}$. Penelitian yang dilakukan Abanihe dan Oke tahun 2011 menyebutkan bahwa ibu dengan usia gestasi yang tergolong awal memiliki kecenderungan untuk melahirkan bayi BBLR dengan risiko 4 kali lebih besar dibanding ibu dengan usia gestasi yang tergolong penuh ${ }^{24}$.

Usia gestasi awal dapat terjadi karena usia ibu dan status gizi saat kehamilan. Usia ibu yang tergolong berisiko memilki masalah kehamilan adalah usia kurang dari 20 tahun dan lebih dari 35 tahun. Ibu yang hamil pada usia kurang dari 20 tahun dapat melahirkan bayi prematur, bayi BBLR, dan mengalami pendarahan saat persalinan ${ }^{25}$ sedangkan ibu yang hamil pada usia lebih dari 35 tahun berisiko melahirkan bayi dengan kelainan genetik ${ }^{16}$. Penelitian yang dilakukan Mendez et.al. tahun 2015 menuliskan bahwa ibu dengan usia kurang dari 20 tahun dan lebih dari 35 tahun melahirkan bayi pada usia gestasi awal jauh lebih banyak dibanding ibu dengan usia antara 20-35 tahun ${ }^{26}$.

Status gizi saat kehamilan dapat dipengaruhi beberapa faktor seperti status gizi sebelum kehamilan, peningkatan berat badan selama kehamilan, dan LILA selama kehamilan ${ }^{28}$. Ambang batas LILA yang dianggap berisiko mengalami KEK adalah $<23,5 \mathrm{~cm}^{29}$. Penelitian yang dilakukan Thawani et.al. tahun 2013 menuliskan bahwa usia gestasi awal dapat terjadi karena status gizi kehamilan yang tergolong KEK. Usia gestasi awal yang dimiliki ibu dapat mengakibatkan bayi memiliki berat lahir rendah ${ }^{30}$.

Berdasarkan Tabel 3 diketahui bahwa sebagian besar bayi lahir dengan berat badan lahir normal dari ibu yang tidak mengalami anemia saat kehamilan trimester 3. Jumlah tersebut sebanyak 39 bayi atau $65,00 \%$ dari keseluruhan responden. Jumlah bayi yang dapat ditemukan dengan berat badan lahir rendah yang dilahirkan dari ibu yang mengalami anemia sebanyak 4 bayi atau $6,67 \%$ dari keseluruhan responden. Berdasarkan uji statistik didapatkan nilai $p=$ 0,044 dengan $\alpha=0,05$ dimana $p<\alpha=0,05$ yang memiliki arti terdapat hubungan anatar kadar $\mathrm{Hb}$ trimester 3 kehamilan dengan berat lahir bayi di wilayah kerja Puskesmas Tambak Wedi Surabaya. Hal tersebut sesuai dengan penelitian yang dilakukan Choirunnisa tahun 2010 dimana dalam penelitian tersebut ditemukan adanya hubungan antara kejadian anemia pada ibu hamil dengan berat lahir bayi. Peneliti tersebut menuliskan bahwa ibu hamil yang mengalami anemia memiliki risiko melahirkan bayi BBLR 7,5 kali lebih besar dibanding ibu hamil yang tidak mengalami anemia $^{11}$. Penelitian lain yang mendukung hal tersebut juga dilakukan oleh Vinta tahun 2017 dimana pada penelitian ini besar risiko yang dimiliki ibu hamil anemia untuk melahirkan 
bayi BBLR sebesar 3 kali lebih besar dari ibu hamil yang tidak mengalami anemia ${ }^{17}$. Kejadian anemia dan kadar $\mathrm{Hb}$ saat kehamilan memiliki peran dalam pertumbuhan janin dimana kadar $\mathrm{Hb}<11 \mathrm{~g} / \mathrm{dl}$ saat kehamilan dapat menyebabkan terjadinya retardasi pertumbuhan janin dalam kandungan ${ }^{31}$.

Berdasarkan hasil penelitian ini ditemukan hasil bahwa variabel usia gestasi dan kadar hemoglobin trimester 3 kehamilan memiliki hubungan dengan berat lahir bayi. Kelebihan dari penelitian ini adalah penelitian ini menarik karena peneliti menganalisis usia gestasi dan kadar $\mathrm{Hb}$ trimester 3 kehamilan dengan berat lahir bayi sedangkan sebagian besar hanya meneliti lingkar lengan atas dan usia ibu dengan berat lahir bayi. Kekurangan dari penelitian ini adalah penelitian ini memiliki desain cross sectional dimana hanya melihat permasalahan pada satu waktu itu saja sehingga dalam penelitian ini hasil yang didapatkan akan jauh lebih maksimal jika dilakukan dengan desain penelitian kohort yang mampu melihat perkembangan masalah yang diteliti selama kehamilan berlangsung.

\section{KESIMPULAN}

Terdapat hubungan antara usia gestasi dan kadar hemoglobin trimester 3 kehamilan di wilayah kerja Puskesmas Tambak Wedi Surabaya. Pencegahan yang dapat dilakukan untuk mencegah terjadinya usia gestasi awal dan anemia saat kehamilan adalah dengan memperbaiki status gizi sebelum kehamilan atau status gizi sejak remaja. Status gizi saat remaja yang tergolong tidak normal dapat meningkatkan risiko kelahiran bayi BBLR. Tindakan yang dapat dilakukan adalah meningkatkan konsumsi makanan agar seimbang dan beragam. Pemberian edukasi terkait usia yang aman untuk hamil juga perlu diberikan oleh bidan Puskesmas kepada para remaja untuk menghindari kehamilan pada usia ibu yang berisiko untuk melahirkan bayi BBLR.

Pemerintah diharapkan dapat membantu menurunkan angka kejadian BBLR dengan beberapa cara salah satunya adalah sosialisasi lebih lanjut terkait fungsi dan manfaat dari pengonsumsian tablet tambah darah serta keragaman konsumsi pangan selama kehamilan. Penelitian lanjutan terkait BBLR di wilayah kerja Puskesmas Tambak Wedi diharapkan dapat dilakukan sehingga mampu mengetahui faktor apa yang paling berpengaruh terhadap berat lahir bayi. Penggunaan desain penelitian kohort pada penelitian lanjutan diharapkan dapat dilakukan untuk mengurangi terjadinya bias saat penelitian.

\section{ACKNOWLEDGEMENT}

Terima kasih penulis berikan kepada seluruh dosen dan staf Prodi Ilmu Gizi Universitas Airlangga terutama kepada dosen pembimbing atas bimbingan yang diberikan kepada penulis.

\section{REFERENSI}

1. Kementerian Kesehatan RI. Peraturan Menteri Kesehatan Republik Indonesia No.75. 2013. Available from http://gizi.depkes.go.id/download/Kebija kan\%20Gizi/PMK\%2075-2013.pdf.

Diakses pada 09 Agustus 2017.

2. Suryati. Faktor-Faktro yang Mempengaruhi Kejadian BBLR di Wilayah Kerja Puskesmas Air Dingin Tahun 2013. Jurnal Kesehatan Masyarakat Andalas 2014; 8(2): 71-77.

3. Monita, F., Suhaimi, D. dan Ernalia, Y. Hubungan Usia, Jarak Kelahiran dan Kadar Hemoglobin Ibu Hamil dengan Kejadian Berat Lahir Bayi Rendah di RSUD Arifin Achmad Provinsi Riau. JOM FK 2016; 3(1): 6-8.

4. Kementerian Kesehatan RI. Profil Kesehatan Indonesia Tahun 2013. 2014. Available from http://www.depkes.go.id/resources/dow nload/pusdatin/profil-kesehatanindonesia/profil-kesehatan-indonesia2013.pdf. Diakses pada 09 Agustus 2017.

5. Dinas Kesehatan Kota Surabaya. Profil Kesehatan Tahun 2015. 2015. Available from

http://www.depkes.go.id/resources/dow nload/profil/PROFIL_KAB_KOTA_2015/35 
78_Jatim_Kota_Surabaya_2015.pdf. Diakses pada 09 Agustus 2017.

6. Kementerian Kesehatan RI. Profil Kesehatan Indonesia Tahun 2014. 2015. Available from http://www.depkes.go.id/resources/dow nload/pusdatin/profil-kesehatanindonesia/profil-kesehatan-indonesia2014.pdf. Diakses pada 07 Agustus 2017.

7. Oktovusi, S. N. Faktor-Faktor yang Mempengaruhi Bayi Berat Lahir Rendah di Puskesmas Banguntapan I Bantul Yogayakarta. Skripsi.Yogyakarta: Sekolah Tinggi IImu Kesehatan 'Aisyiyah Yogyakarta; 2013.

8. Spong, C. Y. Defining "Term" Pregnancy. Recommendations From the Defining "Term" Pregnancy Workgroup. JAMA 2013; 309(23): 2.445-2.446.

9. Pereira, A.P.E., Leal, M. D.C., Gama, S. G. N. D., Domingues, R. M. S. M., Schilithz, A. O. C., Bastos, M. H. Determining Gestational Age Based on Information From the Birth in Brazil Study. Methodological Issues 2014; 30(1): 1-12.

10. Gill, S. V., May-Benson, T. A., Teasdale, A., Munsell, E. G. Birth Development Correlates of Birth Weight in A Sample of Children With Potential Sensory Processing Disorder. BMC 2013; 13(29): 1-8.

11. Choirunnisa, M. L. Hubungan Kenaikan Berat Badan, Lingkar Lengan Atas dan Kadar Hemoglobin Ibu Hamil Trimester III dengan Kejadian Berat Badan Lahir Rendah Di Kota Surakarta. Skripsi. Surakarta: Universitas Sebelas Maret; 2010.

12. WHO. Haemoglobin concentrations for the diagnosis of anaemia and assessment of severity. Vitamin and Mineral Nutrition Information System 2011; 11(1): 1-6.

13. Sharma, J. B. \& Shankar, M. Anemia in Pregnancy. JIMSA 2010; 23(4): 253- 260.

14. Putri, U. R. Hubungan Antara Kadar Hemoglobin Ibu Hamil Pada Trimester Ketiga Dengan Antropometri Bayi Baru Lahir di RSPAD Gatot Soebroto Ditkesad. Skripsi. Jakarta: Universitas Islam Negeri Syarif Hidayatullah; 2014.
15. Muhdar, H. M., Muis, M., Yusuf, R. M., Hamid, $N$. The Influence of Spiritual Intelligence, Leadership, and Organizational Citizenship Behavior and Employees Performance (A Study on Islamic Banks in Makassar, South Sulawesi Province, Indonesia). The International Journal of Business \& Management 2015; 3(1): 297-314.

16. Sibuea, M. D., Tendean, H. M. M. dan Wagey, F. W. Persalinan Pada Usia $\geq 35$ Tahun di RSU Prof. Dr. R. D. Kandou Manado. Jurnal e-biomedik 2013; 1(1): 484-489.

17. Wati, L. M. Faktor-Faktor yang Berhubungan dengan Kejadian BBLR (Berat Badan Lahir Rendah) di RSUD Ambarawa Tahun 2013. Skripsi. Semarang: Sekolah Tinggi Ilmu Kesehatan Ngudi Waluyo; 2014.

18. Mayanda, V. Hubungan Status Gizi Ibu Hamil Dengan Berat Badan Lahir Rendah (BBLR) RSIA Mutia Sari Kecamatan Mandau. Jurnal Menara Ilmu 2017; 11(74): 4-8.

19. Beck, K. L., Conlon, C. A., Kruger, R., Coad, J. Dietary Determinants of and Possible Solutions to Iron Deficiency for Young Women Living in Industrialized Countries: A Review. Nutrients 2014; 6(9): 3.7473.776.

20. Nur, R., Arifuddin, A. \& Novilla R. Analisis Faktor Risiko Kejadian Berat Badan Lahir Rendah di Rumah Sakit Umum Anitapura Palu. Jurnal Preventif 2016; 7(1): 1-14.

21. Pinontoan V. M. \& Tombokan, S.G.J. Hubungan Umur dan Paritas Ibu dengan Kejadian Bayi Berat Lahir Rendah. Jurnal Ilmiah Bidan 2015; 3(1): 20-25.

22. Sulistyorini, Suci. Faktor-Faktor yang Berhubungan Dengan Kejadian Bayi Berat Lahir Rendah di Irna Kebidanan dan Penyakit Kandungan RSUP Dr. Mohammad Hosein Palembang Tahun 2013. Jurnal Harapan Bangsa 2013; 1(2): 1-10.

23. Nejad, N.H., Pejhan, A., Rakhshami, M. H., Hoseini, B.L. The Incidence of Low Birth (LBW) AND Small-for-Gestational Age (SGA) and its Related Factors in 
Neonates, Sabzevar, Iran. IJP 2014; 6(2): 73-78.

24. Abanihe, U. C. I. \& Oke, O. A. Maternal and Environment Factors Influencing Infant Birth Weight in Ibadan, Nigeria. African Population Studies 2011; 25(2): 250-267.

25. Kementerian Kesehatan RI. Profil Kesehatan Indonesia Tahun 2015. 2016. Available from http://www.depkes.go.id/resources/dow nload/pusdatin/profil-kesehatanindonesia/profil-kesehatan-Indonesia2015.pdf. Diakses pada 07 Agustus 2017.

26. Mendez, M. C. R., Lawlor, D. A., Horta, B. L., Matijasevich, A., Santos, I. S., Menezes, A. M. B., Barros, F. C., Victora, C. G. The Association of Maternal Age with Birth Weight and Gestational Age: A Cross-Cohort Comparison. Paediatric and Perinatal Epidemiology 2015, 29(1): 3140.
27. Ariastuti, A. R. Hubungan Pengetahuan Gizi Ibu Hamil dan Frekuensi Pemeriksaan Kehamilan dengan Status Gizi Ibu Hamil di Puskesmas 2 Colomadu. Skripsi. Surakarta: Universitas Muhammadiyah; 2012.

28. Kementerian Kesehatan RI. Profil Kesehatan Indonesia Tahun 2012. 2013. Available from http://www.depkes.go.id/resources/dow nload/pusdatin/profil-kesehatanindonesia/profil-kesehatan-indonesia2012.pdf. Diakses pada 09 Agustus 2017

29. Thawani, R., Dewan, P., Faridi, M. M. A., Arora, S. K., Kumar, R. Estimation of Gestational Age, Using Neonatal Anthropometry: A Cross-sectional Study in India. J Health Popular Nutrition 2013, 31(4): 523-530.

30. Tabrizi, F. M.Barjasteh, S. Maternal Hemoglobin Levels during Pregnancy and Their Association with Birth Weight of Neonates 2015, 5(4): 211-217. 